\title{
Maximizing growth rate at low temperatures: RNA:DNA allocation strategies and life history traits of Arctic and temperate Daphnia
}

\author{
G. J. Van Geest $\cdot$ R. Sachse $\cdot$ M. Brehm • \\ E. Van Donk $\cdot$ D. O. Hessen
}

Received: 22 August 2009/Revised: 30 March 2010/ Accepted: 30 April 2010/Published online: 23 May 2010

(C) The Author(s) 2010. This article is published with open access at Springerlink.com

\begin{abstract}
Many short-lived or univoltine organisms at high latitudes and altitudes face the challenge to complete their life-cycle within a brief growing season. This means that they need to maintain a high growth rate at low temperatures, and one way of doing this is to allocate limiting resources like phosphorus to RNA in order to maximize protein synthesis. We here explore the allocations of phosphorus to RNA relative to DNA, and the potential bearings on growth rate and life history traits of polyploid (high-Arctic) and diploid (temperate) Daphnia pulex. The polyploid clone matured earlier at low temperature $\left(8^{\circ} \mathrm{C}\right)$ but later than the diploid clone at high temperature $\left(18^{\circ} \mathrm{C}\right)$. Juveniles of Arctic Daphnia had both higher specific levels
\end{abstract}

G. J. Van Geest $(\bowtie) \cdot$ M. Brehm · E. Van Donk Department of Food Web Studies, Centre for Limnology, NIOO-KNAW, Rijksstraatweg 6, 3631 AC Nieuwersluis, The Netherlands

e-mail: gerben.vangeest@deltares.nl

R. Sachse

TU Dresden, Ökologische Station Neunzehnhain,

Neunzehnhainerstr. 14, 09514 Lengefeld, Germany

E. Van Donk

Laboratory of Palaeobotany and Palynology,

Institute of Environmental Biology, Palaeoecology,

University of Utrecht, Budapestlaan 4, 3584 CD Utrecht,

The Netherlands

D. O. Hessen

Department of Biology, Center of Ecological and Evolutionary

Synthesis, University of Oslo, Pb. 1064, Blindern,

0316 Oslo, Norway

G. J. Van Geest

Department of Water Quality and Freshwater Ecosystems, Deltares, P.O. Box 85467, 3508 AL Utrecht, The Netherlands of RNA and higher growth rates at low temperature compared with the temperate clone of Daphnia. We hypothesize that Arctic Daphnia may overcome growth constraints posed by low temperature and polyploidy by increasing their allocation of resources to RNA. The prevalence of polyploidy in Arctic populations strongly suggests that the potential drawbacks of polyploidy are counteracted by an increased allocation of resources to RNA to keep a high rate of protein synthesis even under low temperatures.

Keywords Stoichiometry · Polyploidy ·

Cold acclimatization

\section{Introduction}

Mechanisms at the cellular level have received increased attention in ecological studies on thermal adaptation and growth rate in invertebrates (Elser et al. 1996, 2000). A crucial question is how animals cope with the need for high growth rates due to short seasons in cold areas, i.e. how can ectothermic animals maintain relatively high rates of growth and metabolism despite living at low temperatures (Woods et al. 2003). Two hypotheses may explain thermal adaptations in cellular processes: structural changes of enzymes that increase the rate of reaction at low temperature (cold adaptation, Hochachka and Somero 1973), or higher absolute levels of enzymes in cells in support of overall reaction rates (Adamowicz et al. 2002).

A higher enzyme activity at low temperature (cold adaptation) is expected to occur at the expense of performance at higher temperatures e.g. reduced efficiency or increased risk of heat stress at higher temperatures (Yamahira and Conover 2002). On the other hand, higher absolute levels of enzymes would increase reaction rates at 
all temperatures. In support of this, a literature survey found that cold-acclimated ectotherms contained higher cell-specific levels of phosphorus (P) and rRNA than warm-exposed conspecifics (Woods et al. 2003). This is probably due to reduced efficiency of protein synthesis at low temperatures, i.e. a higher level of ribosomes per unit protein produced at low temperatures. As stated in the growth rate hypothesis, RNA is an especially P-rich molecule, which is reflected in higher contents of $\mathrm{P}$ and thus higher $\mathrm{P}$ demands of Arctic animals (Sterner and Elser 2002). Consistent with this hypothesis, Elser et al. (2000) found that body growth rate and P content of individuals of the Daphnia pulex species complex were higher in Arctic water bodies compared to temperate lakes.

In Arctic and alpine regions, many organisms (including Daphnia, Beaton and Hebert 1988) are polyploid. Polyploidy is regarded as an adaptation to low temperature (Otto and Whitton 2000). Generally, polyploids have slower growth and delayed developmental rates compared with their diploid conspecifics at standard culturing temperatures (e.g. $15^{\circ}-20^{\circ} \mathrm{C}$; Weider 1987). Under low temperatures, however, polyploid members of the $D$. pulex complex mature faster than their diploid counterparts, which may give polyploid clones a head start over diploids at the onset of the reproductive season in the Arctic when water temperature is low (Dufresne and Hebert 1998).

Currently, there is a lack of knowledge to what extent basic physiological traits (like growth rate or cold tolerance) are affected by polyploidy at different temperatures, and if polyploidy is an adaptive trait under these circumstances. Increased genome size or various levels of genome duplication plays an important role in evolution of both plants and animals (Gregory 2001; Lynch 2007), and whole or partial genome duplication may serve as an "allelic backup" against mutations in the absence of recombination for obligatory asexual organisms like Arctic Daphnia. On the other hand, given the fact that Daphnia commonly face dietary P limitation of growth rate (Sterner and Elser 2002), there might also be a "competition" for $P$ between RNA and DNA (Hessen et al. 2008) that should counteract large genome size or polyploidy.

To explore the relative allocations of $\mathrm{P}$ to RNA relative to DNA, and the potential bearings of RNA concentrations and polyploidy on growth rate, we compared temperaturerelated shifts in life history traits and specific content of nucleic acids of polyploid (high-Arctic) and diploid (temperate) members of the Daphnia pulex species complex. Based on the observation that diploid and arctic polyploid clones of Daphnia show consistent differences in life history strategies (Dufresne and Hebert 1998; Elser et al. 2000), we wanted to test if such differences in growth and life history could be linked to nucleic acids allocation strategies. These experiments should give insight into physiological regulation of life history traits in relation to ploidy level and temperature, as well as the evolutionary trade-offs related to these adaptations.

\section{Materials and methods}

Animals

Since different species inhabit central Europe and the high Arctic, we could not run tests on the same species for both regions. However, both clones used in the experiments belonged to the Daphnia pulex species complex. One temperate clone of Daphnia pulex was isolated in 1998 from a shallow pond at Nieuwersluis (The Netherlands: latitude $52^{\circ}$ ) and was cultured in laboratory prior to experiments. In 1998, polar Daphnia pulicaria was isolated from a pond close to Ny-Ålesund (Svalbard: latitude $79^{\circ}$; species have been identified according to Weider and Hobæk 2003). Microsatellite screening confirmed that the clone was polyploid as has previously also been inferred by the prevalence of unbalanced polymorphism (unpubl. data). The use of single clones precludes general conclusions about Arctic versus temperate populations, but our intention is primarily to build on the extensive study of Dufresne and Hebert (1998) where they demonstrated consisted life history differences between polyploid and diploid clones from the Arctic and test whether this potentially could be attributed to RNA:DNA allocation strategies.

Prior to the life history experiment, individuals of both temperate and Arctic clones were cultured for at least three generations at 8,13 , and $18^{\circ} \mathrm{C}$ in $100 \mathrm{ml}$ filtered lake water (0.45- $\mu \mathrm{m}$ membrane) from Lake Maarsseveen (The Netherlands) containing a suspension of unicellular Scenedesmus $(\sim 2 \mathrm{mg} \mathrm{C} / \mathrm{l})$ with a C:P ratio of approximately 135 . Length-weight regressions were determined separately for the Arctic and temperate clone at $18^{\circ} \mathrm{C}$, according to the formula $W=a \times L^{b}(\mathrm{~W}=$ dry weight; $\mathrm{L}=$ length; a, $\mathrm{b}=$ constants; for both clones, $R^{2}$ was 0.98 ).

\section{DNA/RNA content of neonates}

Neonates (age $<24 \mathrm{~h}$ ) of a temperate $D$. pulex and a polar D. pulicaria cultured for 3 years at $8^{\circ} \mathrm{C}$ or $18^{\circ} \mathrm{C}$ respectively were preserved in RNA-later $\left({ }^{\circledR}\right.$ Ambion) and stored frozen at $-20^{\circ} \mathrm{C}$. The mothers of these individuals were cultivated at optimal feeding conditions (see above). For each treatment ( 2 clones $\times 2$ temperatures), nine replicates were used. Subsequently, RNA and DNA content of individual first instar Daphnia was determined with a microfluorometric assay using Ribogreen $\left({ }^{\circledR}\right.$ Molecular Probes) according to Kyle et al. (2003). 


\section{Life history experiment}

The life history experiments lasted from February 21st 2004 to May, 7th 2004. At the start of the experiments, neonates (age $<24 \mathrm{~h}$ ) of the arctic and temperate clone were put individually in $100 \mathrm{ml}$ tubes and cultured at 8,13 , and $18^{\circ} \mathrm{C}$, respectively. This resulted in six treatments $(2$ clones $\times 3$ temperatures). Each treatment consisted of 14 randomly chosen newborns originating from at least three mothers. For each treatment, the water was changed every other day (food concentration approximately $2 \mathrm{mg} \mathrm{C}^{-1}$ ) and the average $\mathrm{C}: \mathrm{P}$ ratio of the algae $( \pm \mathrm{SD})$ was $153 \pm 25$. Animals were examined regularly for moulting, body length (measured by an ocular micrometer on a microscope, to the nearest $0.1 \mathrm{~mm}$; measured from just above the eye to the base of the tail spine), time needed to reach maturity (days), size at maturity (mm), and the number of newborns for each brood were recorded. Newborns were removed from the tubes within $24 \mathrm{~h}$. The life history experiments were ended after the animals had reached the fourth adult instar and consequently had released their third clutch.

\section{Temperature transfer experiment}

The effect of cold acclimatization on somatic growth rate was determined for the Arctic and temperate clone. Both clones were pre-cultivated at temperatures of 8 and $18^{\circ} \mathrm{C}$ respectively for a period of 3 years at optimal feeding conditions (see above). This should be sufficient for phenotypic adaptation (acclimatization) of protein synthesis. At the start of the experiment, neonates (age $<24 \mathrm{~h}$ ) of the temperate and Arctic clone that had been cultured at $8^{\circ} \mathrm{C}$ for 3 years were translocated to $18^{\circ} \mathrm{C}$ to check for shortterm phenotypic responses in somatic growth rate in response to elevated temperature. As control treatments, neonates of both clones were manipulated the same way without changing temperature (i.e. transferred from $18^{\circ}$ to $18^{\circ} \mathrm{C}$ ). Each treatment consisted of 10 neonates that were individually cultured in $100 \mathrm{ml}$ tubes. Somatic growth rate $\left(d^{-1}\right)$ was calculated by the following formulae:

$g=\frac{\ln \left(M_{\mathrm{t}}\right)-\ln \left(M_{0}\right)}{t}$

where $M_{\mathrm{t}}$ is the final body mass, $M_{0}$ is the neonate body mass on day 0 , and $t$ is the duration of the experiment (days). Body mass was estimated from length-weight regressions of the animals in laboratory, as explained above.

Survival experiments

To test the effects of extreme low water temperature on survival of Arctic and temperate Daphnia, 20-35 neonates (age $<24 \mathrm{~h}$ ) of both clones (that were pre-cultivated for a period of 3 years at optimal feeding conditions at $8^{\circ} \mathrm{C}$ ) were translocated to $0^{\circ} \mathrm{C}$. In the Arctic, temperatures close to $0^{\circ} \mathrm{C}$ are realistic for Daphnia, as many young daphnids can already been seen in Arctic lakes and ponds that are for a large part covered by melting ice. The animals were placed in 100-ml bottles in a container with (regularly refreshed) melting ice in a refrigerator. The medium contained a suspension of unicellular Scenedesmus ( $\sim 2 \mathrm{mg} \mathrm{C} / \mathrm{l}$ ) with a C:P ratio of approximately 120 and was refreshed every second day. Survival of the animals was recorded every day.

Algae used during the experiments

The green algae Scenedesmus obliquus (Turpin) Kützing (Chlorococcales, Chlorophyta), UTEX 2630 was obtained from the Norwegian Institute for Water Research (NIVA, Norway). The algae were cultured in 21 chemostats (continuously illuminated at an irradiance of $70 \mu \mathrm{E} \mathrm{m}^{-2} \mathrm{~s}^{-1}$ ) on COMBO medium (Kilham et al. 1998) at a dilution rate of 0.1 day $^{-1}$. The algae were then centrifuged, and subsequently resuspended in filtered lake water $(0.45 \mu \mathrm{m}$ membrane) from Lake Maarsseveen (Maarssen, The Netherlands).

\section{Chemical analysis}

For determination of algal $\mathrm{C}$ and $\mathrm{P}$ content, $150 \mathrm{ml}$ of algal culture material was filtered through $0.45-\mu \mathrm{m}$ glass fibre filters. The filters were dried overnight at $60^{\circ} \mathrm{C}$, after which dry weight was measured. Algal $\mathrm{C}$ content was calculated assuming a conversion factor of 0.53 from dry weight to carbon (Winberg 1971). For determination of algal P, the filters were combusted for $2 \mathrm{~h}$ at $550^{\circ} \mathrm{C}$, after which $\mathrm{P}$ content was measured according to Murphy and Riley (1962). For each sample, 4-6 replicates were used.

\section{Statistical analyses}

Where normal distribution of data was confirmed, two-way ANOVA was used for assessment of the effects of temperature and clone type, and their interaction term, subsequently followed by Bonferroni post hoc testing $(P<0.05)$. When a normal distribution could not be achieved even after log-transformation, a non-parametric test (Wilcoxon/Kruskal-Wallis) was applied.

\section{Results}

DNA/RNA content of neonates

Specific RNA and DNA content of the first instar was significantly affected by temperature, clone type, and 
interaction between temperature and clone type, while the ratio of RNA to DNA was only significantly affected by the interaction term (Table 1; Fig. 1). Weight-specific RNA content was significantly higher for the Arctic clone relative to the temperate clone at both 8 and $18^{\circ} \mathrm{C}$ (Fig. 1). This was also found for weight-specific DNA content at both temperatures. For Arctic Daphnia, RNA content was higher at $18^{\circ} \mathrm{C}$ compared to $8^{\circ} \mathrm{C}$ (Fig. 1), whereas such differences were not detected for the temperate clone. At $18^{\circ} \mathrm{C}$, RNA:DNA ratio was significantly higher in the Arctic clone compared to the temperate clone, but at $8^{\circ} \mathrm{C}$ no significant differences were detected between the temperate and Arctic clone (Fig. 1).

\section{Life history experiment}

Two-way ANOVA revealed a significant effect of temperature, clone type and interaction of temperature $\times$ clone type on age of first reproduction, size at maturity, and size of neonates (Table 2). The number of neonates was significantly affected by both temperature and clone type, but not by the interaction term (Table 2). Overall, the Arctic clone had a larger size at day zero as well as a greater age at maturity (Fig. 2b, c), and a strongly reduced number of neonates at all temperatures compared to the temperate clone (Fig. 3). Comparing the two different temperatures, the Arctic clone matured earlier than the temperate clone when they were exposed to $8^{\circ} \mathrm{C}$ (Fig. 2a), despite the difference in the number of moulting phases, which was 7 for the Arctic clone and 6 for the temperate clone (up to age of first reproduction). At $18^{\circ} \mathrm{C}$, however, the temperate clone matured earlier than the Arctic clone (Fig. 2a).

For juvenile somatic growth rate, the normal distribution could not be achieved when all data were pooled together. Therefore, significant differences between growth rate of

Table 1 Two-way ANOVA table of RNA and DNA content, and ratio of RNA:DNA of first instar animals of the two clones

\begin{tabular}{llll}
\hline & Clone & Temp & $\begin{array}{l}\text { Interaction } \\
\text { Clone } \times \text { Temp }\end{array}$ \\
\hline RNA/drw & & \\
F & $\mathbf{7 5 . 5}$ & $\mathbf{6 . 0 4}$ & $\mathbf{6 . 8 3}$ \\
P & $<\mathbf{0 . 0 0 0 0 0 1}$ & $\mathbf{0 . 0 1 9}$ & $\mathbf{0 . 0 1 3}$ \\
DNA/drw & & & \\
F & $\mathbf{8 2 . 5}$ & $\mathbf{8 2 . 5}$ & $\mathbf{1 2 . 6}$ \\
P & $<\mathbf{0 . 0 0 0 0 0 1}$ & $<\mathbf{0 . 0 0 0 0 0 1}$ & $\mathbf{0 . 0 0 1 2}$ \\
Ratio RNA/DNA & & & \\
F & 4.03 & 0.482 & $\mathbf{8 . 8 5}$ \\
P & 0.053 & 0.49 & $\mathbf{0 . 0 0 5 5}$ \\
\hline
\end{tabular}

Statistical significant results are indicated bold (post hoc Bonferroni test $P<0.05)$ the Arctic and temperate clone were tested for each temperature separately. Juvenile somatic growth rate of the Arctic clone was significantly higher than for $D$. pulex at $8^{\circ}$ $(t$-test, $P<0.001)$ and $18^{\circ} \mathrm{C}($ Kolmogorov-Smirnov Test,
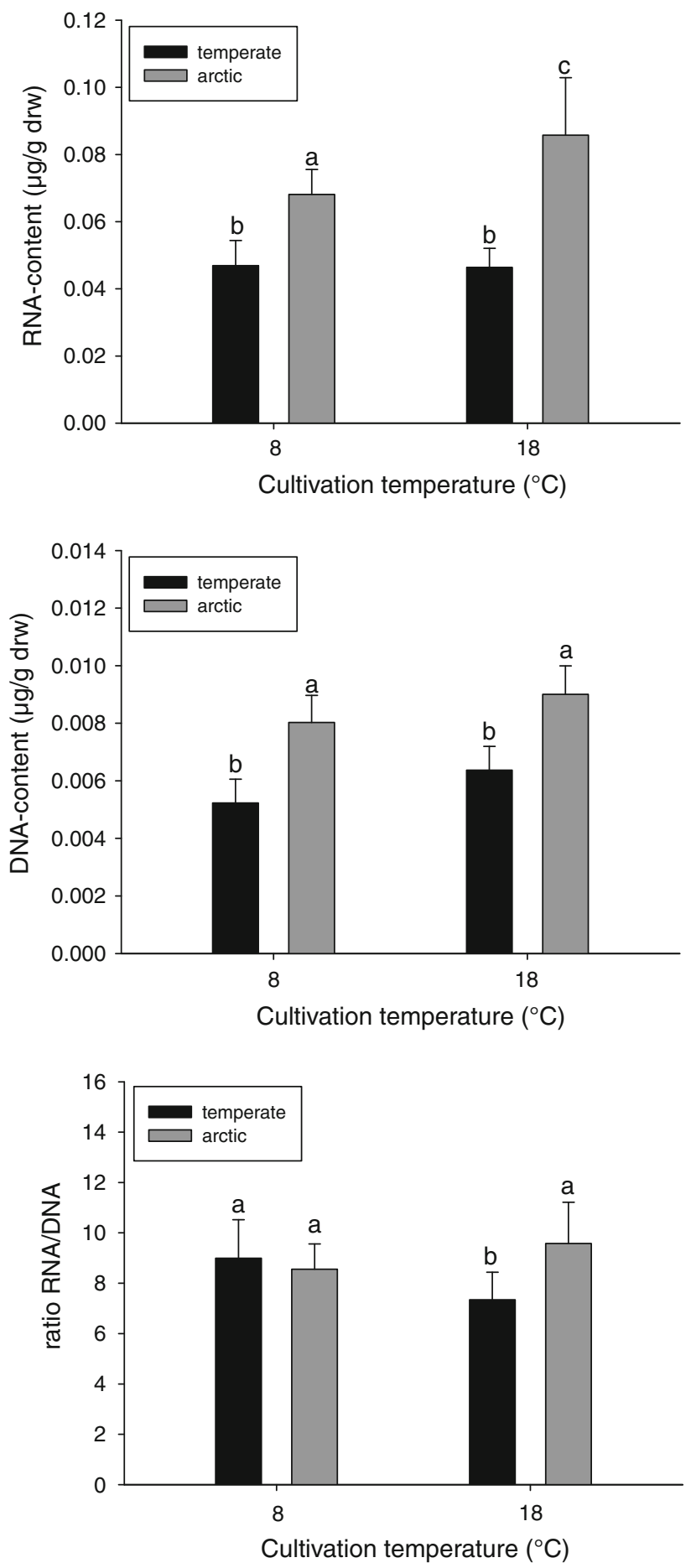

Fig. 1 RNA content, DNA content, and ratio of RNA:DNA of arctic and temperate Daphnia cultivated at $8^{\circ}$ and $18^{\circ} \mathrm{C}$, respectively. Statistical differences are indicated with different letters (Bonferroni test; $P<0.05)$. Error bars indicate standard deviations 
Table 2 Two-way ANOVA table of age of first reproduction (AFR), size of neonates, size at maturity (SAM), and number of neonates

\begin{tabular}{llll}
\hline & Clone & Temp & $\begin{array}{l}\text { Interaction } \\
\text { clone } \times \text { Temp }\end{array}$ \\
\hline AFR & & & \\
F & $\mathbf{8 . 4 2}$ & $\mathbf{8 6 7 . 8}$ & $\mathbf{2 1 . 8}$ \\
P & $\mathbf{0 . 0 0 4}$ & $<\mathbf{0 . 0 0 0 0 0 1}$ & $<\mathbf{0 . 0 0 0 0 0 1}$ \\
Size neonates & & & \\
F & $\mathbf{1 7 0 . 9}$ & $\mathbf{1 1 . 0}$ & $\mathbf{1 5 . 9 5}$ \\
P & $<\mathbf{0 . 0 0 0 0 0 1}$ & $\mathbf{0 . 0 0 0 0 4}$ & $\mathbf{0 . 0 0 0 0 0 1}$ \\
SAM & & & \\
F & $\mathbf{1 7 2 . 1}$ & $\mathbf{4 . 2}$ & $\mathbf{3 . 7 9}$ \\
P & $<\mathbf{0 . 0 0 0 0 0 1}$ & $\mathbf{0 . 0 1 7}$ & $\mathbf{0 . 0 2 5}$ \\
$n$ 1 st clutch & & & \\
F & $\mathbf{3 3 . 2}$ & $\mathbf{8 . 6 0}$ & 2.81 \\
P & $<\mathbf{0 . 0 0 0 0 0 1}$ & $\mathbf{0 . 0 0 0 3}$ & 0.06 \\
$n$ 2st clutch & & & \\
F & $\mathbf{1 1 . 0}$ & $\mathbf{9 . 1 9}$ & 0.48 \\
P & $<\mathbf{0 . 0 0 1 3}$ & $\mathbf{0 . 0 0 0 2}$ & 0.62 \\
$n$ 3st clutch & & & \\
F & $\mathbf{2 7 . 2}$ & $\mathbf{7 . 6 9}$ & 2.20 \\
P & $\mathbf{0 . 0 0 0 0 0 1}$ & $\mathbf{0 . 0 0 0 8}$ & 0.12 \\
\hline & & &
\end{tabular}

Statistical significant results are indicated in bold (post hoc Bonferroni test; $P<0.05$ )

$P<0.001)$, but did not differ significantly at $13^{\circ} \mathrm{C}$ ( $t$-test, $P=0.36$; Fig. 4).

\section{Temperature transfer experiment}

During the temperature transfer experiment, somatic growth rate was significantly related to pre-cultivation temperatures (two-way ANOVA; Bonferroni testing: $F=9.0 ; \quad P=0.0053$ ), but not to clone type or the interaction term $(P=0.42$ and 0.14 , respectively). For Arctic Daphnia, pre-cultivation at $8^{\circ} \mathrm{C}$ resulted in a lower growth rate at $18^{\circ} \mathrm{C}(P=0.016)$ compared to the control treatment (viz. transfer from $18^{\circ}$ to $18^{\circ} \mathrm{C}$; Fig. 5), whereas no significant differences were detected for the temperate clone.

\section{Survival experiments}

During the survival experiment at $0^{\circ} \mathrm{C}$, the average life span ( \pm s.d.) for the Arctic clone was significantly higher than that for the temperate clone $(29.7 \pm 8.5$ versus $8.6 \pm 3.9, t$-test, $P<0.01)$. For the temperate clone, none of the individuals moulted. For the Arctic clone, some of the individuals moulted for the first time after 17 days, but no animal was able to reach age of first reproduction.
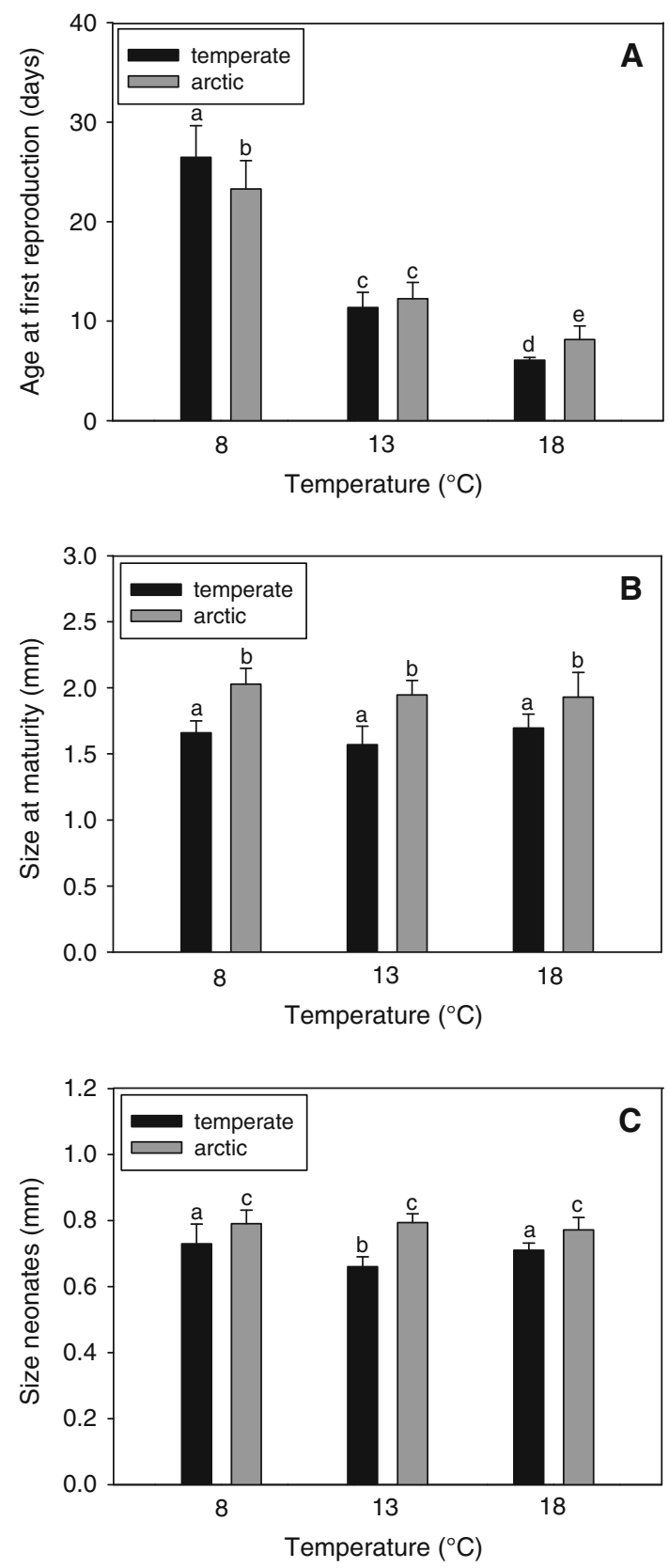

Fig. 2 Age at first reproduction, size at maturity and size of neonates of arctic and temperate Daphnia cultivated at $8^{\circ}, 13^{\circ}$, and $18^{\circ} \mathrm{C}$, respectively. Statistical differences are indicated with different letters (Bonferroni test; $P<0.05$ ). Error bars indicate standard deviations

\section{Discussion}

Our experiments demonstrated a general better performance of the Arctic clone relative to the temperate clone at low temperatures with regard to developmental rate and survival, while not for clutch size at any of the three first instars. Admittedly, these conclusions are based on two clones only, but the life history experiments confirm the results of Dufresne and Hebert (1998) based on a number 

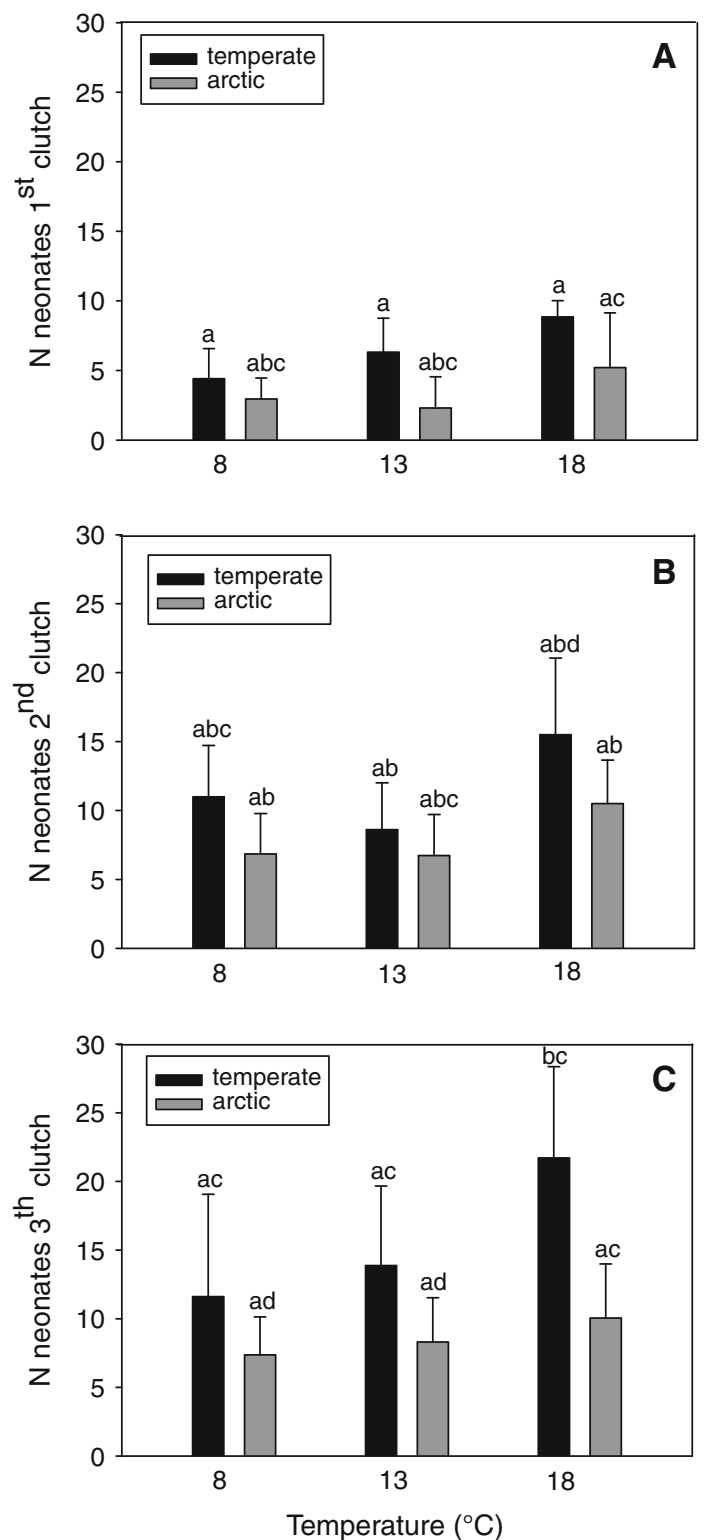

Fig. 3 Number of neonates of Arctic and temperate Daphnia cultivated at $8^{\circ}, 13^{\circ}$, and $18^{\circ} \mathrm{C}$, respectively. Statistical differences are indicated with different letters (Bonferroni test; $P<0.05$ ). Error bars indicate standard deviations

of diploid and polyploid clones of Daphnia that were collected in the Arctic. In the life history experiments of Dufresne and Hebert (1998), polyploid clones had larger neonates, as well as larger body sizes than diploid clones under 10,17 , and $24^{\circ} \mathrm{C}$. In addition, in their experiment, polyploid clones matured earlier than diploid clones at low temperature $\left(10^{\circ} \mathrm{C}\right)$, but later at high temperature $\left(24^{\circ} \mathrm{C}\right.$; Dufresne and Hebert 1998). Furthermore, polyploid clones had fewer neonates than diploid clones in their experiment at all temperatures (Dufresne and Hebert 1998). Assuming that these differences between diploid and polyploid clones are general traits, our aim was here primarily to see how

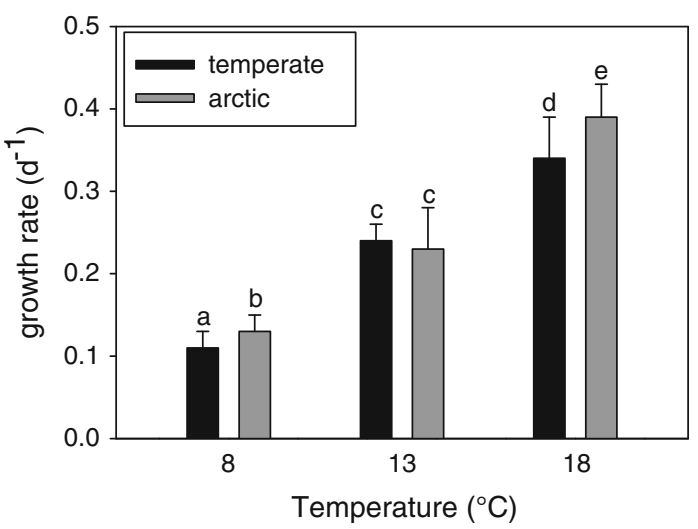

Fig. 4 Somatic growth rate of Arctic and temperate Daphnia cultivated at $8^{\circ}, 13^{\circ}$, and $18^{\circ} \mathrm{C}$, respectively. Statistical differences were tested for each temperature separately $\left(8^{\circ}, 13^{\circ}: t\right.$-test; $18^{\circ} \mathrm{C}$ : Kolmogorov-Smirnov Test) and are indicated with different letters. Error bars indicate standard deviations

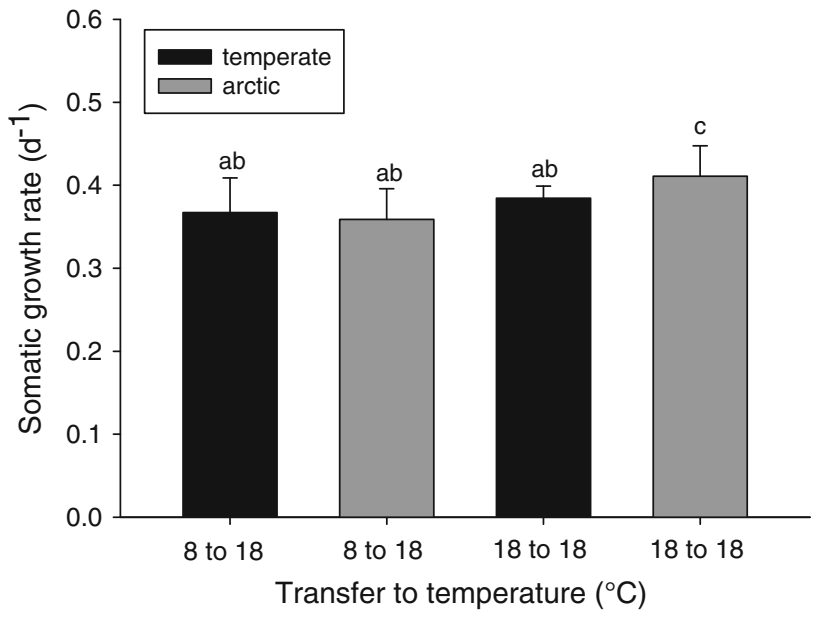

Fig. 5 Somatic growth rate of arctic and temperate Daphnia at $18^{\circ} \mathrm{C}$ of individuals pre-cultivated at $8^{\circ}$ and $18^{\circ} \mathrm{C}$, respectively. Statistical differences are indicated with different letters (Bonferroni test; $P<0.05)$. Error bars indicate standard deviations

these life history traits and growth rate strategies could be linked with P allocations to RNA relative to DNA in Arctic polyploids compared to temperate diploids. Our results are in line with the Growth Rate Hypothesis (Elser et al. 1996; Sterner and Elser 2002), which states that individual RNA content is positively related to somatic growth rate. It also supports previous studies demonstrating higher specific content of P (and RNA) of Arctic compared to temperate Daphnia (Elser et al. 2000). One way on increasing protein synthesis would be an elevated ribosomal efficiency, which has been demonstrated by Weider et al. (2005). However, elevated specific RNA content of individuals most likely reflect a higher cell-specific number of ribosomes as means to increase the rate of protein synthesis (i.e. a quantitative rather that a qualitative response), which may compensate for the overall low enzyme kinetics at low temperatures. 
In our life history experiment, the polyploid Arctic clone matured earlier at low temperature, but later at high temperature compared to their diploid temperate counterpart. Similar results have been obtained during a life history experiment with Daphnia pulex which were collected from the Canadian low-Arctic, in which polyploid clones also matured earlier at low temperature but later than diploid clones at high temperature (Dufresne and Hebert 1998). Prokopowich et al. (2003) found a positive correlation between rDNA copy number and genome size across a range of organisms, yet we do not know whether the increased amount of DNA in polyploids promotes high levels of RNA and hence high rate of protein synthesis in cells. Higher DNA contents caused by polyploidy in Arctic species could also reflect the larger cell size and larger body size at low temperatures. In fact irrespective of polyploidy, it is a common observation for Arctic species (including crustaceans) that they have typically large genomes which correlate well with large cell and body size (Gregory 2001, 2008; Rees et al. 2007; Hessen and Persson 2009). Normally, this should imply lower cell division rates, unless compensated for by higher RNA levels.

Accelerated growth via enhanced RNA levels and polyploidy involves a major $\mathrm{P}$ investment in ribosomes (Hessen 1990; Elser et al. 1996). Consequently, polyploid Arctic organisms will have an increased demand for $\mathrm{P}$, which may be constrained by low P content of the food, especially in generally nutrient-poor Arctic ponds (Van Geest et al. 2007). Therefore, it can be expected that selection should favour some P-sparing mechanisms, as the animal that develops fastest per unit $\mathrm{P}$ used will be favoured in competition (Elser et al. 1996; Hessen et al. 2008). Polyploidy is, in this context, somewhat of a puzzle since it implies more P allocated to DNA. Daphnia, however, has a strongly miniaturized genome with typically haploid C values of $0.17-0.63$ pg DNA cell ${ }^{-1}$ (Gregory 2008). Hence, polyploidy may not be that costly in terms of $\mathrm{P}$ after all, because RNA makes up the main bulk of cellular P. Accordingly, RNA:DNA ratios were similar or even higher for the Arctic clone compared to the temperate conspecific (Fig. 1). As an additional P-saving mechanism, phosphorus excretion may also be strongly reduced by Arctic Daphnia compared to temperate daphnids (Elser et al. 2000).

The reduced brood size of polyploid Daphnia could be a trade-off for providing the neonates with an increased amount of $\mathrm{P}$, so that the neonates can transcribe more RNA and compensate for low temperatures in Arctic ponds. A strongly reduced brood size compared to diploid conspecifics has also been reported for polyploid Daphnia pulex from the Canadian low-Arctic (Dufresne and Hebert 1998), as well as for several polyploid Arctic clones from
Svalbard (belonging to polar Daphnia pulicaria and D. tenebrosa; Alfsnes 2007).

Interestingly, low temperature did not increase RNA levels for any of the clones compared to $18^{\circ} \mathrm{C}$, even after 3 years of cultivation at these temperatures. Hence, the levels of nucleic acids seem to be a generic property of the clones adapted to different temperatures. The prevalence of polyploidy in Arctic populations strongly suggests that the potential drawbacks of being polyploid are offset by other means to boost growth rate under low temperatures. Based on our study, we hypothesize that an increased allocation of resources to RNA to keep a high rate of protein synthesis even under low temperatures. To confirm these findings, however, a wider range of both temperate and Arctic clones need to be screened for RNA:DNA ratios, and additional life history experiments should be conducted for these clones.

Open Access This article is distributed under the terms of the Creative Commons Attribution Noncommercial License which permits any noncommercial use, distribution, and reproduction in any medium, provided the original author(s) and source are credited.

\section{References}

Adamowicz SJ, Gregory TR, Marinone MC, Hebert PDN (2002) New insights into the distribution of polyploid Daphnia: the Holarctic revisited and Argentina explored. Mol Ecol 11:1209-1217

Alfsnes K (2007) Polyploidy in Daphnia-methodology and effects on life history traits. Mr Sc Thes, Univ Oslo, Dept Biol

Beaton MJ, Hebert PDN (1988) Geographical Parthenogenesis and Polyploidy in Daphnia pulex. Am Nat 132:837-845

Dufresne F, Hebert PDN (1998) Temperature-related differences in life-history characteristics between diploid and polyploid clones of the Daphnia pulex complex. Ecoscience 5:433-437

Elser JJ, Dobberfuhl DR, MacKay NA, Schampel JH (1996) Organism size, life history, and N:P stoichiometry. Bioscience 46:674-684

Elser JJ, O'Brien WJ, Dobberfuhl DR, Dowling TE (2000) The evolution of ecosystem processes: growth rate and elemental stoichiometry of a key herbivore in temperate and arctic habitats. J Evol Biol 13:845-853

Gregory TR (2001) Coincidence, coevolution, or causation? DNA content, cell size, and the C-value enigma. Biol Rev 76:65-101

Gregory TR (2008) Animal Genome Size Database. http://www. genomesize.com

Hessen DO (1990) Carbon, nitrogen and phosphorus status in Daphnia magna at varying food conditions. J Plankton Res 12:1239-1249

Hessen DO, Persson J (2009) Genome size as a determinant of growth rate and life history traits in crustaceans. Biol J Linn Soc 98:393-399

Hessen DO, Ventura M, Elser JJ (2008) Do phosphorus requirements for RNA limit genome size in crustacean zooplankton? Genome 51:685-691

Hochachka PW, Somero GN (1973) Strategies of biochemical adaptation. WB Saunders, Philadelphia

Kilham SS, Kreeger DA, Lynn SG, Goulden CE, Herrera L (1998) COMBO: a defined freshwater culture medium for algae and zooplankton. Hydrobiol 377:147-159 
Kyle M, Watts T, Schade J, Elser JJ (2003) A microfluorometric method for quantifying RNA and DNA in terrestrial insects. J Insect Sci 3:1-7

Lynch M (2007) The origins of genome architecture. Sinauer Assoc, Mass

Murphy J, Riley JP (1962) A modified single solution method for determination of phosphate in natural waters. Anal Chim Acta 26:31-36

Otto SP, Whitton J (2000) Polyploid incidence and evolution. Ann Rev Genet 34:401-437

Prokopowich CD, Gregory TR, Crease TJ (2003) The correlation between rDNA copy number and genome size in eukaryotes. Genome 46:48-50

Rees DJ, Dufresne F, Glemet H, Belzile C (2007) Amphipod genome sizes: first estimates for Arctic species reveal genomic giants. Genome 50:151-158

Sterner RW, Elser JJ (2002) Ecological stoichiometry: the biology of elements from molecules to the biosphere. Princeton University Press, Princeton

Van Geest GJ, Hessen DO, Spierenburg P, Dahl-Hansen GAP, Christensen G, Færovig PJ, Brehm M, Loonen MJJE, Van Donk E (2007) Goose-mediated nutrient enrichment and planktonic grazer control in arctic freshwater ponds. Oecologia 153:653662

Weider LJ (1987) Life history variation among low-arctic clones of obligately parthenogenetic Daphnia pulex - a diploid-polyploid complex. Oecologia 73:251-256

Weider LJ, Hobæk A (2003) Glacial refugia, haplotype distributions, and clonal richness of the Daphnia pulex complex in arctic Canada. Mol Ecol 12:463-473

Weider LJ, Elser JJ, Crease TJ, Mateos M, Cotner JB, Markow TA (2005) The functional significance of ribosomal (r)DNA variation: impacts on the evolutionary ecology of organisms. Ann Rev Ecol Evol Syst 36:219-242

Winberg GG (1971) Methods for estimating the production of populations with continuous reproduction. In: Winberg GG (ed) Methods for the estimation of production of aquatic animals. Academic Press, London

Woods HA, Makino W, Cotner JB, Hobbie SE, Harrison JF, Acharya K, Elser JJ (2003) Temperature and the chemical composition of poikilothermic organisms. Funct Ecol 17:237-245

Yamahira K, Conover DO (2002) Intra- vs. interspecific latitudinal variation in growth: adaptation to temperature or seasonality? Ecol 83:1252-1262 